\title{
Effect of Two Patterns of Intercropping Soybean with Maize on Yield and Its Components under Different Nitrogen Fertilizer Levels
}

\author{
E.A. Rashwan ${ }^{\#}$ and A.A. Zen El- Dein" \\ Department of Agronomy, Faculty of Agriculture, Tanta University, Tanta and \\ *Intensification Crops Res. Dept., Field Crops Res. Institute, Agric. Res. Center, \\ Cairo, Egypt.
}

\begin{abstract}
T WO FIELD experiments were carried out at Zarzoura, Itay El-Baroud, Agricultural Research Station, El-Behaira Governorate, Agricultural Research Center (ARC), Egypt during 2014 and 2015 seasons to study the effects of three nitrogen fertilizer levels on yield and yield components under two intercropping soybean/maize patterns. The results indicated that, the highest ear length, ear diameter, No. of rows per ear, grain yield per ear (for maize), seed yield per fad (for soybean) and the better (the lowest) competitive ratio values were found with treatment intercropping patterns 2 maize: 4 soybean (CP2). While the highest grain yield per fad (for maize), No. of pods per plant, seed yield per plant (for soybean), total LER (land equivalent ratio), the percentage land saved, total AYL (actual yield loss) and WUE (water use efficiency) values were occurred under intercropping patterns 2 maize: 2 soybean (CP1).

Moreover, plant height, ear length, No. of grains per row, grain yield per fad, ear height, ear diameter, No. of rows per ear, grain yield per ear,100- grains weight (for maize), plant height, No. of branches per plant, No. of pods per plant, seed yield per plant and per fad (for soybean), total LER, the percentage land saved, total AYL, aggressivity and WUE values were increased with the increment in nitrogen level, and the highest values were obtained with $120 \mathrm{~kg} / \mathrm{fad}$, while the lowest values were obtained with $80 \mathrm{~kg} / \mathrm{fad}$. On the other hand, No. of seeds per pod and 100 seed weight for soybean had a negative relationship with the level of nitrogen applied and its highest values were obtained with $80 \mathrm{~kg} / \mathrm{fad}$.
\end{abstract}

Keywords: Competition characters, Equivalent yield, Intercropping patterns, Maize and soybean yields, Net return and nitrogen levels.

\section{Introduction}

Sustainable agriculture is a type of agriculture that is aiming to increase the efficiency of resources utilization, provide needs of people today and for future generations, restore diversity to agricultural ecosystems and accomplish balance with the environment through its effective management (Mousavi \& Eskandari, 2011). Intercropping is a way to increase diversity in the agricultural ecosystem, which is the combination between two or more crops in the same field and growing season (Fathi, 2014). Intercropping is considered an example of sustainable agricultural systems that contribute in achieving ecological balance, more utilization of available growth resources such as nutrients, water, and light, increase the productivity per unit of land and reduce yield damage by pests, diseases and weeds (Brooker et al., 2015). Consequently, the yields of intercrops may exceed the yield sum of the corresponding sole crops. (Miyazawa et al., 2010). The majority of intercropping systems mostly involve legume/ cereal combinations due to its interspecific facilitation or complementarity (Loreau et al., 2001).

Many studies were conducted to evaluate the productivity of maize/soybean intercropping systems, for example, Waktola et al. (2014) reported that, the productivity of maize-soybean intercropping showed a higher relative yield advantage over sole cropping. Also, Sani et al. (2014) found that, the corn yield was higher in intercropping than monoculture crops. In addition, maize based intercropping system with legume helps in improving soil health as well as yield crop (Beedy et al., 2010).

Maize plant development is strongly dependent on the abundant of soil nitrogen and

\footnotetext{
\#Corresponding author e-mail: plant_breeding2000@yahoo.com DOI: 10.21608/agro.2017.1627.1074
}

C2017 National Information and Documentation Centre (NIDOC) 
nitrogen use efficiency for biomass production and yield (Sonnewald, 2012). On the other hand, soybean is considered a legume plant, which has the ability to fix atmospheric nitrogen when properly nodulated, and so is less dependent for growth on sources of nitrogen from the soil. (Flynn \& Idowu, 2015).

Therefore, keeping in view the above mentioned aspects, the objective of this investigation was to study the effect of two different patterns of maize/ soybean intercropping on yield and its components under three nitrogen fertilizer levels.

\section{Materials and Methods}

The present investigation was carried out in the experimental farm of Zarzoura, Itay ElBaroud, Agricultural Research Station, ElBehaira Governorate, Agricultural Research Center (ARC), during the two successive growing summer seasons 2014 and 2015 to study the effects of three nitrogen fertilizer levels on yield and yield components under two intercropping soybean/ maize patterns and on water use efficiency under solid and intercropping patterns.

Soil properties and meteorological records of the experiment site, are Tabulated in Tables 1 and 2 , respectively.

The used hybrid maize was (white single cross S.C. 122) while, the used soybean cultivar was (Giza 111).

The experimental treatments were arranged in a split plot design with three replicates, two cropping patterns (CP) were randomly allocated in the main plots:

$(\mathrm{CP} 1)=$ Two rows of maize: Two rows of soybean. (This pattern was expressed as 100\% maize $+50 \%$ soybean).

$(\mathrm{CP} 2)=$ Two rows of maize: Four rows of soybean. (This pattern was expressed as $66.66 \%$ maize $+66.66 \%$ soybean).

The sub-plots were randomly assigned by three nitrogen fertilizer levels

$(\mathrm{N} 1)=80$ Nitrogen units $(\mathrm{kg})$ per fad $\left(4200 \mathrm{~m}^{2}\right)$

$(\mathrm{N} 2)=100$ Nitrogen units $(\mathrm{kg})$ per fad $\left(4200 \mathrm{~m}^{2}\right)$

$(\mathrm{N} 3)=120$ Nitrogen units $(\mathrm{kg})$ per fad $\left(4200 \mathrm{~m}^{2}\right)$

These nitrogen fertilizer levels were determined to cover the requirements of maize crop, trying to exploit the ability of soybean plants to fix the atmospheric nitrogen, expecting that, the residues of the applied nitrogen will act as an activator dose to the nodules on the roots of soybean plants. Moreover, a sufficient amount of a bio-fertilizer containing $\mathrm{N}_{2}$ fixing bacteria (Bradyrhizobia japonicum) was applied to soybean seeds before sowing directly and success of nodulation was assessed after 30 days from sowing by counting more than ten healthy nodules per root. On the other hand, the nitrogen fertilizer was added in the form of urea $(46 \% \mathrm{~N})$ in two doses, the first half was added before the first irrigation and the second half was added before the second irrigation.

The preceding crop was wheat in both seasons; the intercropping patterns were sown at $2^{\text {nd }}$ and $1^{\text {st }}$ of June 2014/15, respectively. Each sub-plot $\left(42 \mathrm{~m}^{2}\right)$ included 10 ridges, each ridge was $7 \mathrm{~m}$ long and $0.6 \mathrm{~m}$ wide $(4.2$ $\mathrm{m}^{2}$ ). Sowing of maize grains was only on the southern side of ridges and its plants were thinned to two plants/hill in the intercropping patterns with distance of $30 \mathrm{~cm}$ between hills. However, sowing of soybean seeds was on both sides of ridges and its plants were thinned to 2 plants/hill with distance of $20 \mathrm{~cm}$ between hills. All another cultural practices for maize and soybean production were undertaken as recommended.

Sowing of the solid crops was at the same time of intercropping patterns, with the recommended density (23000 and 140.000 plants/fad for maize and soybean, respectively), and also fertilized with the recommended doses of the nitrogen for each crop (120 and 25 Nitrogen units/fad for maize and soybean, respectively).

Surface irrigation was applied five times using a hose with flow rate of 105 liter per minute. The first irrigation (after planting irrigation) was applied on $30^{\text {th }}$ and $25^{\text {th }}$ June in 2014 and 2015 growing seasons, respectively, then irrigation sequence every 15 days.

Both crops were harvested manually at full maturity in $30^{\text {th }}$ September and $15^{\text {th }}$ October in both seasons, for maize and soybean, respectively. 


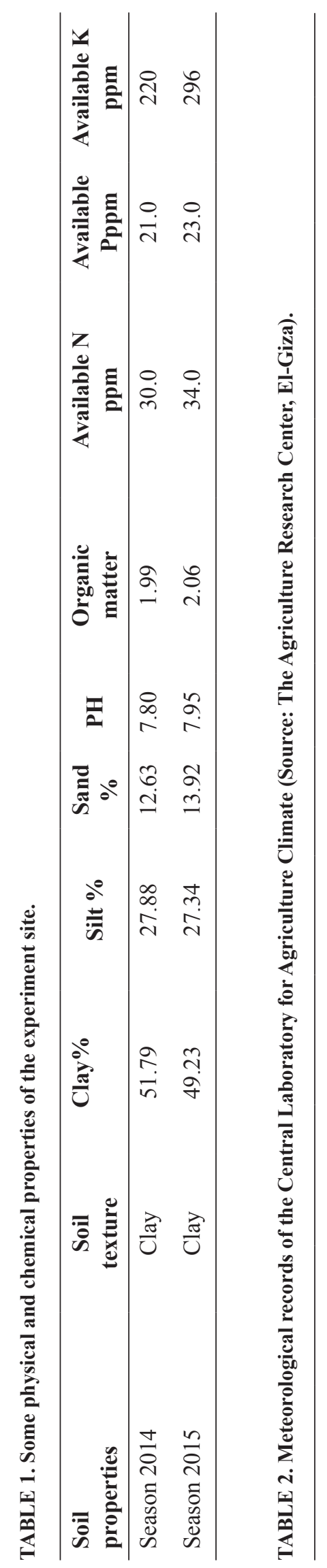

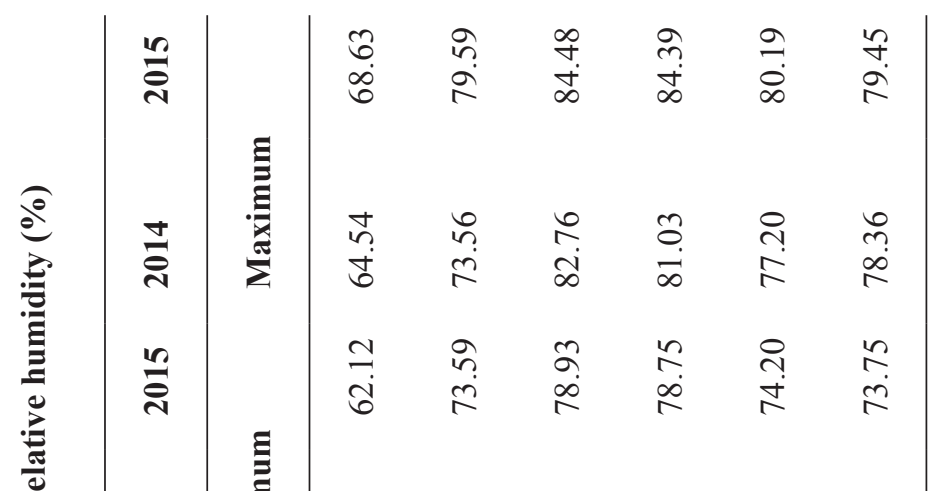

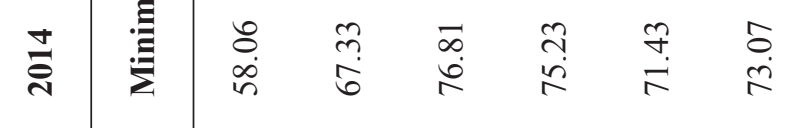

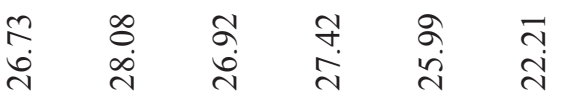

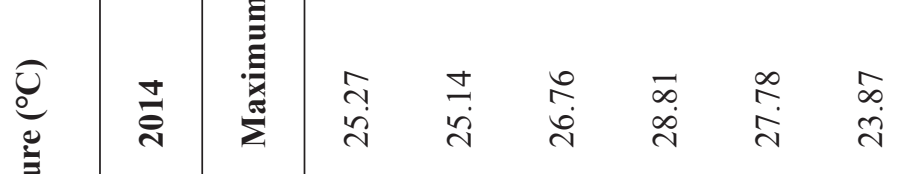

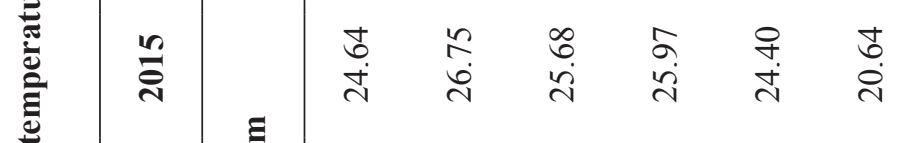

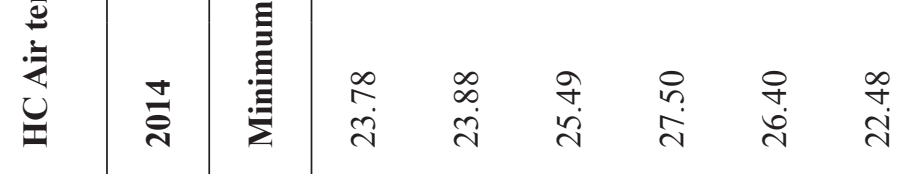

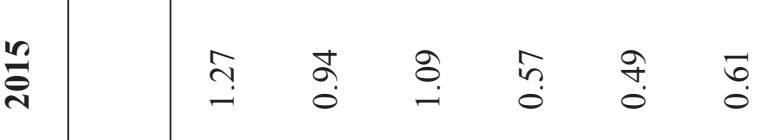

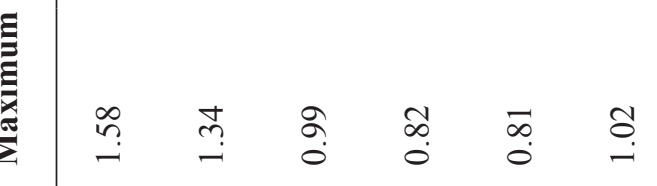

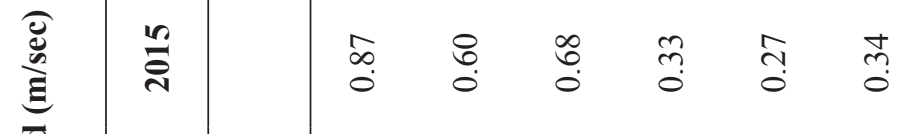

$$
\begin{aligned}
& \text { | }
\end{aligned}
$$


At harvest time the following traits were estimated:

Maize yield and its components:

1- Plant height $(\mathrm{cm})$

2- Ear height $(\mathrm{cm})$.

3- Ear length (cm).

4- Ear diameter $(\mathrm{cm})$.

5 - No. of grains/row.

6- No. of rows/ear.

7- 100- grain weight (g).

8- Grain yield/ear (g).

9- Grain yield/fad (ardab).

Soybean yield and its components:

1- Plant height $(\mathrm{cm})$.

2- No.of branches/plant.

3- No.of pods/plant.

4- No.of seeds/pod.

5- 100-seed weight (g).

6- Seed yield/plant (g).

7- Seed yield/fad $(\mathrm{kg})$.

Evaluation of intercropping pattern (competition characters)

Land equivalent ratio (LER)

The ratio of area need under solid cropping to that of intercropping at the same management level to produce an equivalent yield, according to Mead \& Willey (1980):

$$
\mathrm{LER}=\left(\mathrm{Y}_{\mathrm{ab}} / \mathrm{Y}_{\mathrm{aa}}\right)+\left(\mathrm{Y}_{\mathrm{ba}} / \mathrm{Y}_{\mathrm{bb}}\right)
$$

where, $\mathrm{Y}_{\mathrm{aa}}$ and $\mathrm{Y}_{\mathrm{bb}}$ are the solid crop yields of crops $a$ and $b$, respectively, $Y_{a b}$ is the intercrop yield of crop $\mathrm{a}$, and $\mathrm{Y}_{\mathrm{ba}}$ is the intercrop yield of crop b.

\section{The percentage land saved}

Land saved calculations was another index used to assess the advantage of the intercropping system. It indicates the amount of land saved from intercropping, that could be used for other agricultural purposes. Land saved was calculated according to Willey (1985):

$$
\text { Land saved }(\%)=100-\frac{1}{L E R} X 100
$$

Water use efficiency (WUE)

Water use efficiency values as $\mathrm{kg}$ (grain or seeds) $\mathrm{m}^{-3}$ of applied irrigation water were calculated for different treatments after harvest according to Jensen (1983):

\section{WUE $=\frac{\text { Grain yield }\left(\mathrm{kg} \mathrm{fad}^{-1}\right)}{\text { water applied }\left(\mathrm{m}^{3} \text { fad }^{-1}\right)}$}

Aggressivity (A)

Aggressivity is another index that is often used to indicate how much the relative yield increase in ' $a$ ' crop is greater than that of ' $b$ ' crop in an intercropping system. The aggressivity was formulated according to Dhima et al. (2007):

$\mathrm{A}_{\text {maize }}=\left(\mathrm{Y}_{\mathrm{ab}} / \mathrm{Y}_{\mathrm{a}} \times \mathrm{Z}_{\mathrm{ab}}\right)-\left(\mathrm{Y}_{\mathrm{ba}} / \mathrm{Y}_{\mathrm{b}} \times \mathrm{Z}_{\mathrm{ba}}\right)$

$\mathrm{A}_{\text {soybean }}=\left(\mathrm{Y}_{\mathrm{ba}} / \mathrm{Y}_{\mathrm{b}} \times \mathrm{Z}_{\mathrm{ba}}\right)-\left(\mathrm{Y}_{\mathrm{ab}} / \mathrm{Y}_{\mathrm{a}} \times \mathrm{Z}_{\mathrm{ab}}\right)$

If $\mathrm{A}_{\text {maize }}=0$, both crops are equally competitive,

if $\mathrm{A}_{\text {maize }}$ is positive, then the maize is dominant,

if $\mathrm{A}_{\text {maize }}$ is negative, then the maize is subordinate.

\section{Competitive ratio (CR)}

Competitive ratio indicates the number of times by which one component crop is more competitive than the other. Relative species competition is often evaluated using competitive ratios (Putnam et al., 1984).

$\mathrm{CR}_{\text {maize }}=\left(\mathrm{LER}_{\text {maize }} / \mathrm{LER}_{\text {soybean }}\right)\left(\mathrm{Z}_{\mathrm{ba}} / \mathrm{Z}_{\mathrm{ab}}\right)$

$\mathrm{CR}_{\text {soybean }}=\left(\mathrm{LER}_{\text {soybean }} / \mathrm{LER}_{\text {maize }}\right)\left(\mathrm{Z}_{\mathrm{ab}} / \mathrm{Z}_{\mathrm{ba}}\right)$

where, $Z_{b a}$ is the sown proportion of soybean in the maize/soybean intercrop and $Z_{a b}$ is the sown proportion of maize in the maize/soybean intercrop.

\section{Actual yield loss (AYL)}

The AYL is the proportionate yield loss or gain of intercrops in comparison to the respective solid crop; it takes into account the actual sown proportion of the component crops with its sole stand. The AYL was calculated according to Banik (1996):

$\mathrm{AYL}=\mathrm{AYL} \mathrm{maize}_{\text {m }}+\mathrm{AYL}_{\text {soybean }}$ where $\mathrm{AYL}_{\text {maize }}=\left(\left(\mathrm{Y}_{\mathrm{ab}} / \mathrm{Z}_{\mathrm{ab}}\right) /\left(\mathrm{Y}_{\mathrm{aa}} / \mathrm{Z}_{\mathrm{aa}}\right)\right)-1$, and $\mathrm{AYL}_{\text {soybean }}=\left(\left(\mathrm{Y}_{\mathrm{ba}} / \mathrm{Z}_{\mathrm{ba}}\right) /\left(\mathrm{Y}_{\mathrm{bb}} / \mathrm{Z}_{\mathrm{bb}}\right)\right)-1$

where $Z_{a b}$ and $Z_{b a}$ represent the sown proportion of intercrop maize with soybean, and soybean with maize, respectively.

\section{Crop equivalent yields (CEY) and Farmer's benefit}

\section{Crop equivalent yields (CEY)}

The CEY is the yields of different intercrops/ crops after converted into equivalent yield of any one crop based on price of the product. The CEY was calculated according to Verma \& Modgel (1983) 


$$
\mathrm{CEY}=\mathrm{C}_{\mathrm{y}}+\left(\mathrm{Cl}_{\mathrm{y}} \mathrm{X} \mathrm{P}_{\mathrm{cl}} / \mathrm{P}_{\mathrm{c}}\right)
$$

where, $\mathrm{Cy}$ is the yield of the main crop, the yield of other crops converted to its equivalent and $\mathrm{P}_{\mathrm{c}}$ is its respective price; $\mathrm{Cl}_{\mathrm{y}}$ is the yield of intercrop/other crop which is to be converted to equivalent of main crop yield and $\mathrm{P}_{\mathrm{cl}}$ is its respective price.

Farmer's benefit

Farmer's benefit (L.E) was calculated as a difference between total net returns from intercropping and solid crops.Maize and soybean seeds prices presented by Bulletin of Statistical Cost Production and Net Return were used (the price of maize grains was 300 L.E/ardab and 4000 L.E/ ton for soybean). Total returns were calculated by summing the price of maize yield and the price of soybean yield, whereas, net returns were calculated by subtraction the sum of fixed costs of maize plus variable costs of soybean according to intercropping pattern.

\section{Statistical analysis}

Using Michigan State University Computer Statistical Package (MSTATC), the analysis of variance was used for the two experiments according to Snedecor \& Cochran (1982), the least significant difference (L. S. D) test at 0.05 and 0.01 levels of significance was used to indicate mean comparison of the three nitrogen fertilizer levels.

\section{Results and Discussion}

\section{Maize}

Effect of intercropping patterns on yield and yield components of maize

Data presented in Table 3 showed no significant differences between the two intercropping patterns for plant height, ear height and 100 grain weight in both seasons. However, differences were only significant for ear length, ear diameter and no. of rows per ear only in the second season as well as for grain yield per ear only in the first one.

On the other hand, differences between the two intercropping patterns were highly significant for no. of grains per row in the first season, while it was only significant in the second one. Also, differences were significant for grain yield per fad in both seasons.

Results in Table 3 cleared that, intercropping patterns 2 maize: 4 soybean $(\mathrm{CP} 2)$ had significant increase in all above mentioned significant characters except grain yield per fad, which recorded the highest value with intercropping pattern 2 maize: 2 soybean (CP1). This may be due to its highest plant density compared to the other intercropping pattern. Solid maize recorded the higher grain yield per fad (24.82 and 25.79), compared with intercropped mean (17.10 and 19.55) in both seasons, respectively.

Similar results were found by Matusso (2014), Undie et al. (2012) and Muoneke et al. (2007) who did not find any significant differences in terms of plant height and ear height among the intercropping patterns. Similarly, Thobatsi (2009) found that maize intercropped with cowpea did not have any effect on plant and ear height of maize.

In addition, Abou-Elela et al. (2012) and Metwally et al. (2009) noted that, cropping system 2 maize: 2 soybean had significant increments in grain yield per fad, while cropping system 2 maize: 4 soybean recorded the highest significant values for grain yield per ear in both seasons.

Effect of nitrogen fertilization levels on growth yield and yield components of maize

Data in Table 3 indicated that yield and yield components of maize were increased by increasing nitrogen fertilizer levels. Differences among the three nitrogen fertilizer levels were only significant in the first season and highly significant in the other one for plant height, Ear length, No. of grains per row and grain yield per fad.. However differences were highly significant for ear height, ear diameter, No. of rows per ear and grain yield per ear in both seasons. On the other hand, these differences didn't reach to the $5 \%$ level of significance in the first season and were only significant in the second one for 100 - grains weight. It is obvious that, raising the level of nitrogen up to $120 \mathrm{~kg} / \mathrm{fad}$ exhibited a positive effect on maize yield components. This trend may be due to the vital role of nitrogen in increasing protoplasm formation in plant cells, photosynthesis activity, cell division, meristematic activity in plant organs and consequently increment in area and number of leaves per plant especially when it acts as a catalyst for other nutrients. Similar results were reported by Metwally et al. (2005) and Gadallah \& Gabra (2015) where they reported that, plant height, ear diameter, ear length, number of grains/row, ear grains weight and grain yield per fad of maize were increased by increasing nitrogen fertilizer levels from 90 to $120 \mathrm{~kg} \mathrm{~N} / \mathrm{fad}$. Also, Fathi (2014) concluded that, Nitrogen fertilizer application significantly increased the grain yields and above-ground biomass of maize at all rates of nitrogen application (30, 60 and $120 \mathrm{~kg} / \mathrm{fad}$ ) and the highest grain yield was recorded in maize+soybean intercropping with entire recommended rate of mineral nitrogen application. In addition, Sadeghi \& Kazemeini (2012), revealed that, increasing the nitrogen fertilizer level increased leaf area, plant height and dry weight of maize under different maizebean intercropping patterns. 


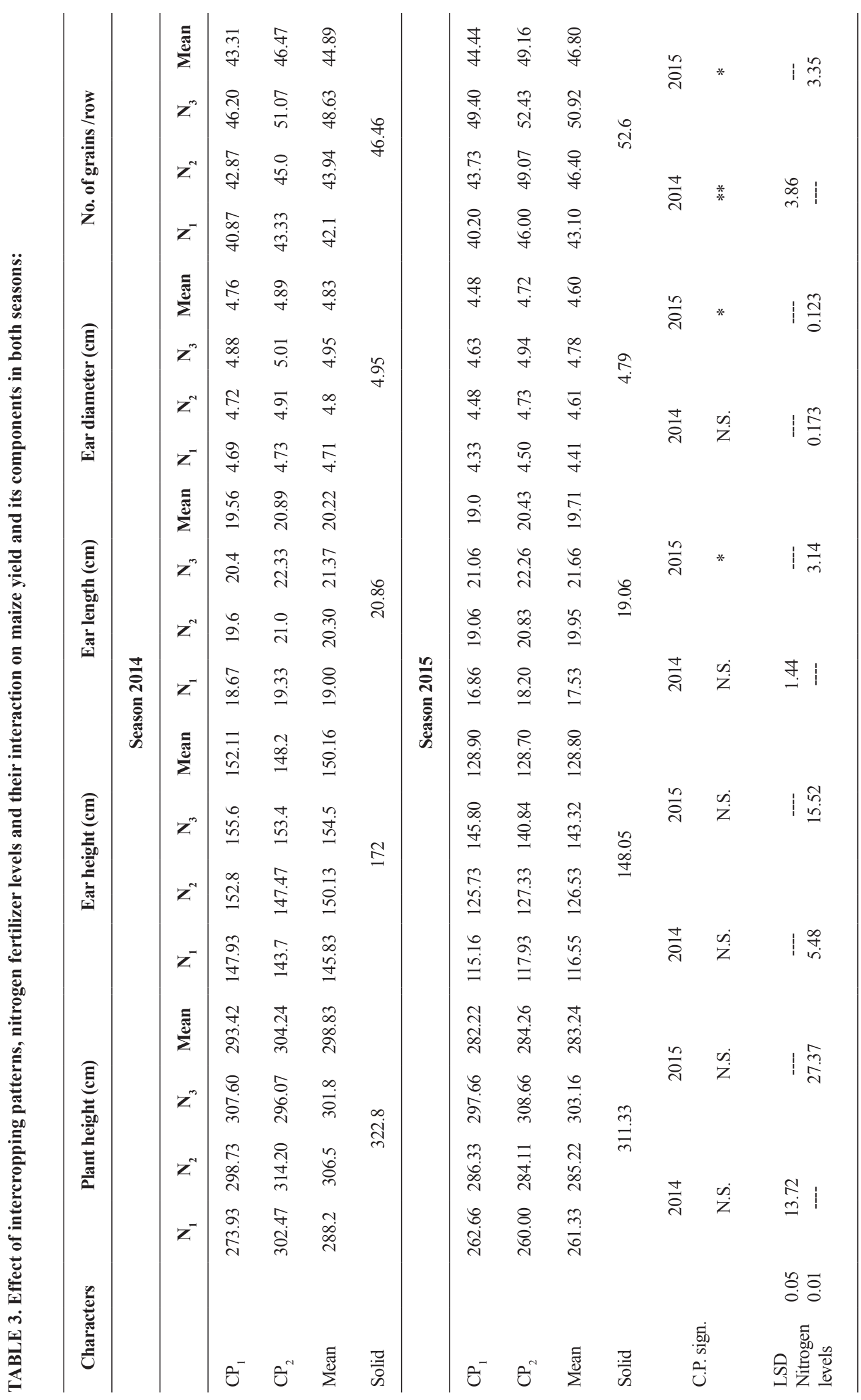

Egypt. J. Agron. 39, №. 3 (2017) 


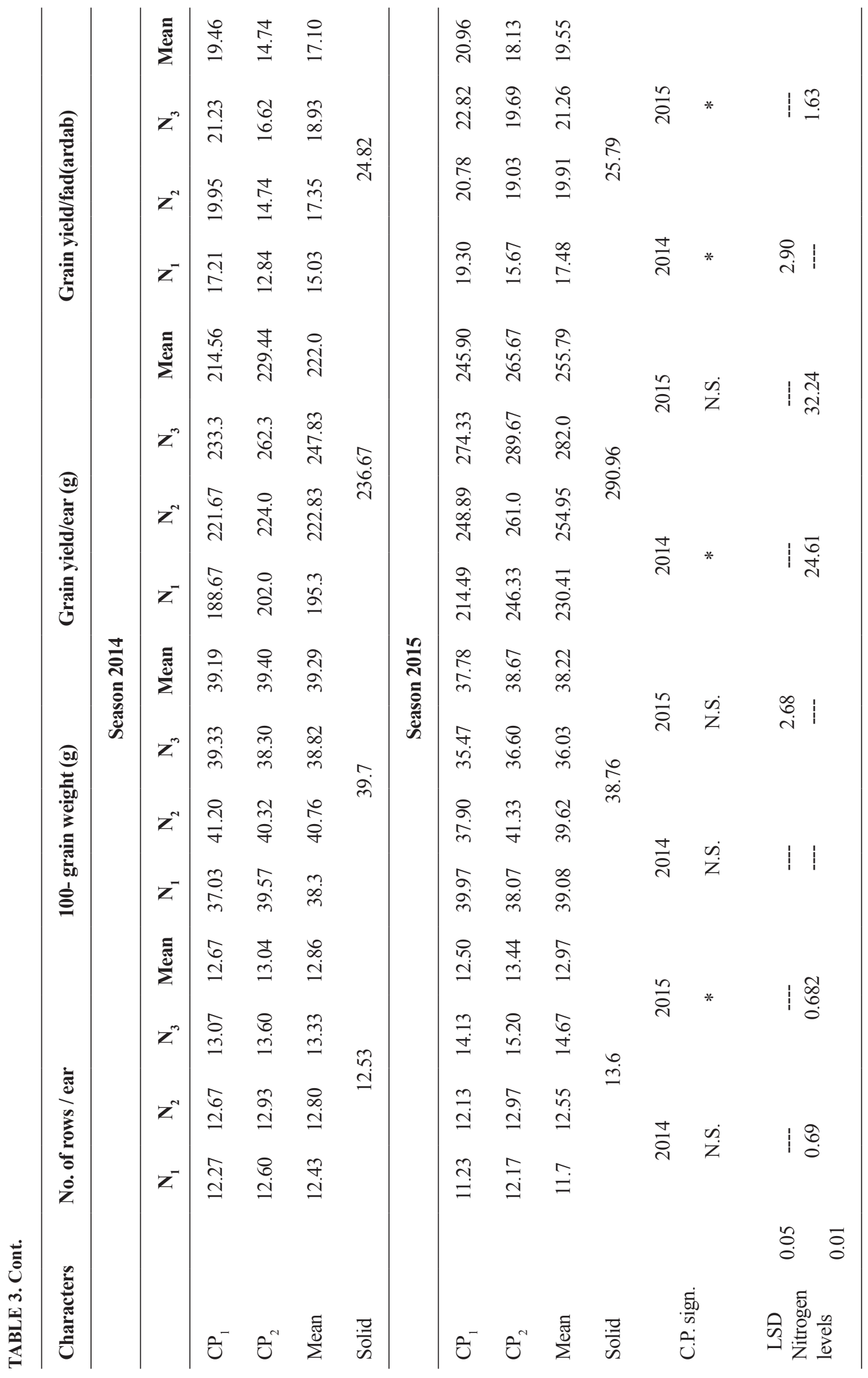




\section{Soybean}

Effect of intercropping patterns on yield and yield components of soybean

Data presented in Table 4 showed no significant differences between the two intercropping patterns for plant height, no. of branches per plant, No. of seeds per pod and 100 seed weight in both seasons. However, differences were only significant for seed yield per plant in the first season only and didn't reach to the $5 \%$ level of significance in the second one. On the contrary, differences between these two intercropping patterns were highly significant for No. of pods per plant and seed yield per fad in both seasons.

It is obvious that, intercropping pattern 2 maize: 4 soybean (CP2) had highly significant increment in seed yield per fad in both seasons comparing with intercropping pattern 2 maize: 2 soybean (CP1). These results may be due to the lower soybean plants density/fad under (CP1) compared with (CP2). On the other hand, the values of No. of pods per plant in both seasons and seed yield per plant in the first one were significantly higher under (CP1) than its under (CP2), which may be due to the lower level of intra competition among soybean plants under (CP1). These data are in agreements with those obtained by Abou-Elela et al (2012) where they found that, intercropping pattern 2 maize: 4 soybean had significant increments in seed yield per fad in both seasons compared with (1 maize: 2 rows soybean and 2 maize: 2 soybean) patterns. In addition Gadallah \& Gabra (2015) reported that, seed yield per fad of soybean increased by increasing plant density from $25 \%$ to $75 \%$ of solid under intercropping pattern.

Also, data in Table 4 cleared that, solid soybean planting had higher values of plant height, No of branches per plant and seed yield per fad than those under intercropping patterns in both seasons. These noticed reductions could be due to the inter-specific competition between the intercrop components for water, light, air and nutrients, and also depressive effect of maize, a C4 species, on soybean, a C3 crop (Egbe, 2010 and Hussain et al., 2013). Also shading by the taller maize plants under the intercropping patterns. This shading could reduce the photosynthetic rate of the lower growing plants and thereby reduce their yields as reported by Zhuang \& Yu-Bi (2013) and Polthanee \& Trelo-ges (2003).
Effect of nitrogen fertilization levels on growth yield and yield components of soybean

Data presented in Table 4 referred that, differences among the three nitrogen fertilizer levels were highly significant in both seasons for all studied traits except No. of seeds per pod, where it was only significant in the first season and didn't reach to the level of significance in the second one. It could be concluded that, in both seasons, increasing the nitrogen fertilizer levels from 80 up to $120 \mathrm{~kg} / \mathrm{fad}$ highly significant increased all studied characters of soybean except No. of seeds per pod and 100 seed weight which had a negative relationship with the level of nitrogen applied. These results could be due to that, nitrogen is an important constituent of protein and protoplasm, enhanced formation in plant cells, photosynthesis activity, cell division, meristematic activity in plant organs and activate the vegetative growth of plants which finally led to increase in plant height and other mentioned traits. Similar results were observed by Undie et al (2010) and Gadallah \& Gabra (2015), where they noted that, increasing nitrogen levels from 90 to 120 $\mathrm{kg} /$ fad significantly increased all soybean studied characters under different intercropping patterns.

\section{Evaluation of intercropping pattern (competition characters)}

Effect of intercropping patterns and nitrogen fertilization levels on land equivalent ratio (LER) and the percentage land saved.

Data in Table 5 showed that, in both seasons, intercropping patterns increased LER and recorded yield advantages as compared to solid plantings of maize and soybean.

The land equivalent ratio (LER) is the relative area of a solid crop required to produce the yield achieved by intercropping. According to Jabbar et al. (2009) when LER value is equivalent to one, it implies that there is no yield advantage, but when LER is more than one, it means that, there is a yield advantage. Data cleared that, LER values were greater than one in both intercropping patterns and the range of yield advantage over solid cropping was between 39 and $45 \%$ in the first season and about $46 \%$ in the second one. These results are in the same line with these obtained by Abou-Elela et al. (2012), El-Sherif \& Ali (2015) as well as Gadallah \& Gabra (2015), when they noted that, in general, intercropping patterns increased LER values and recorded yield advantages when compared with solid plantings of maize and soybean. 


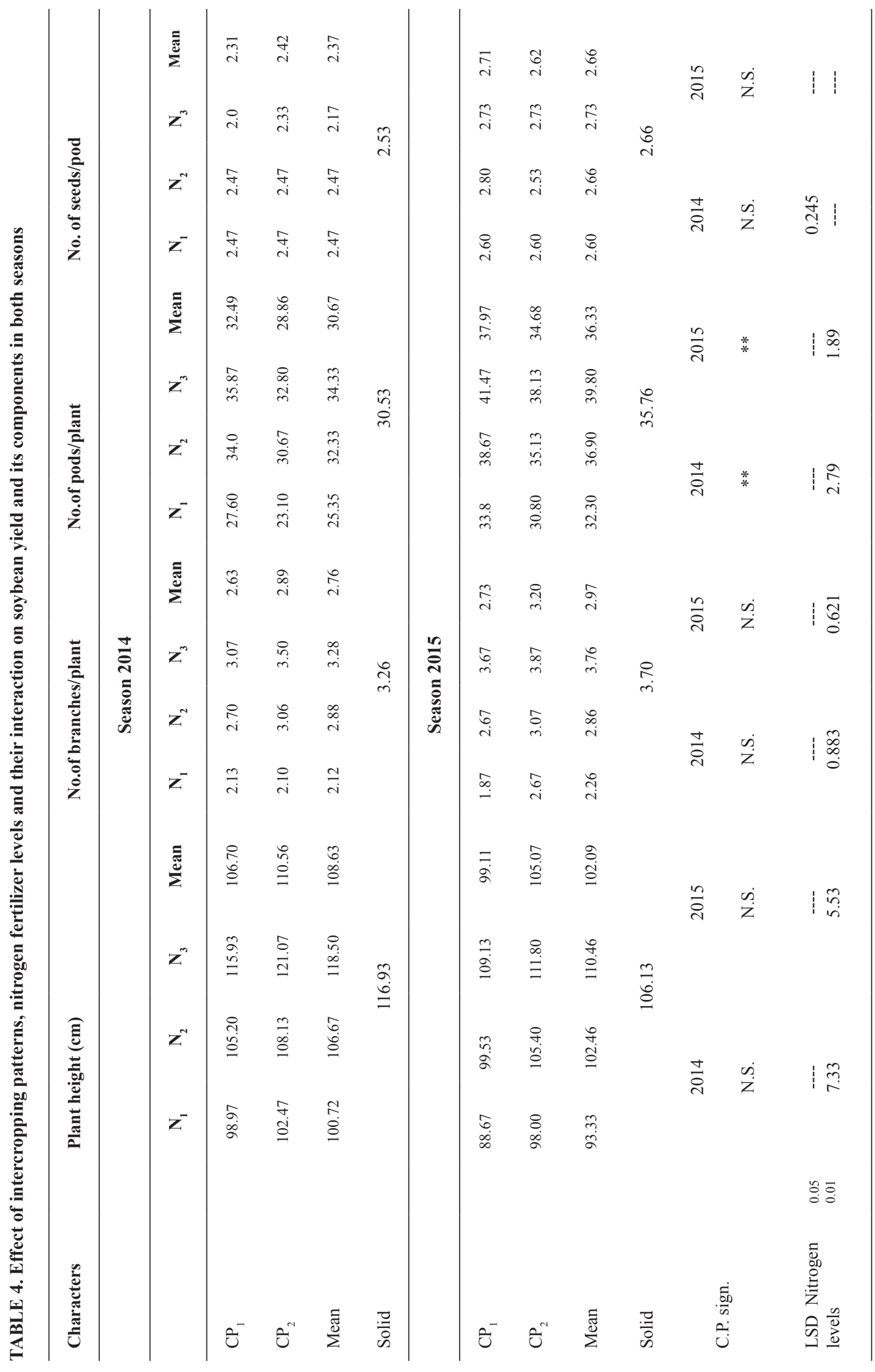




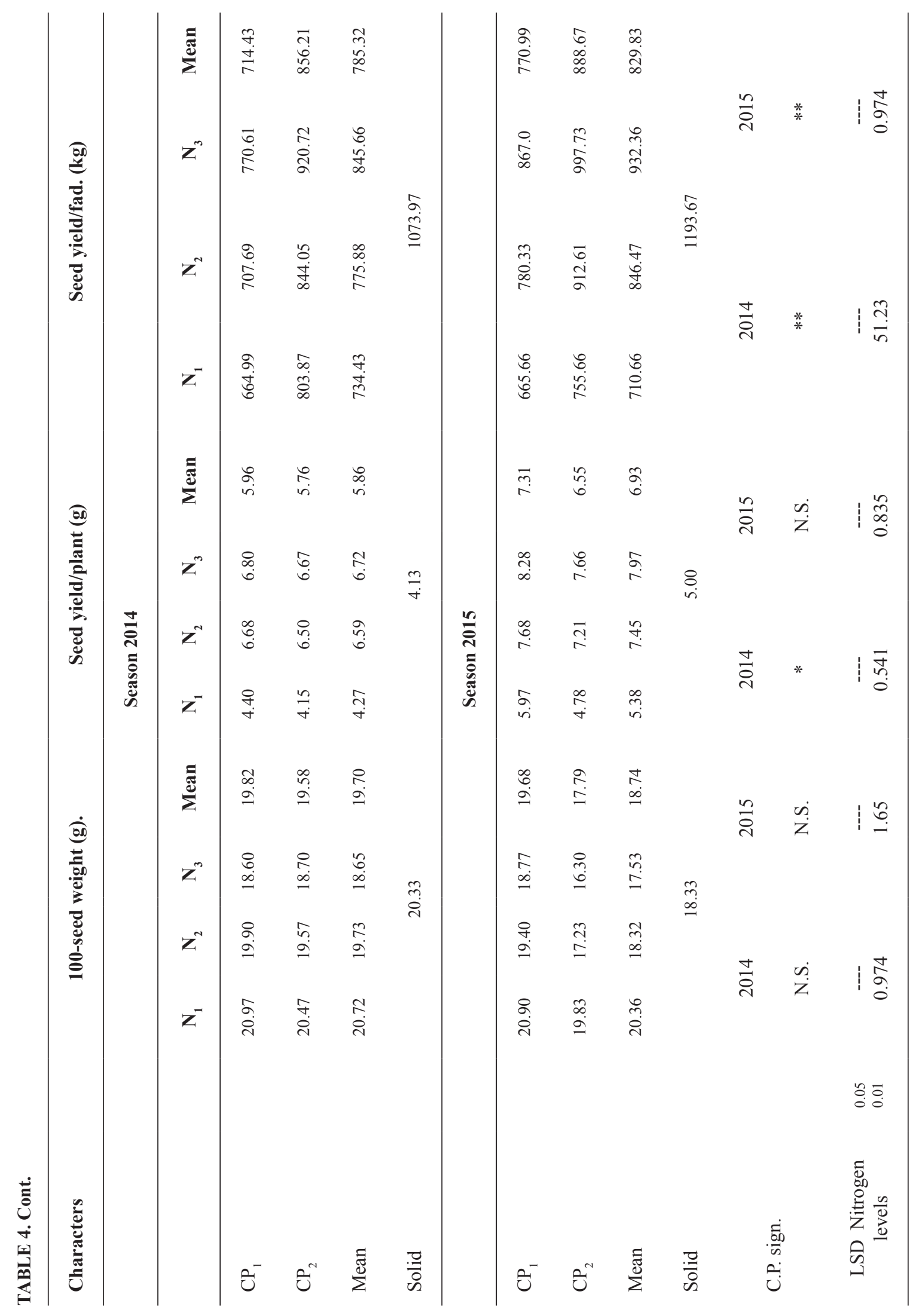

Egypt. J. Agron. 39, №. 3 (2017) 


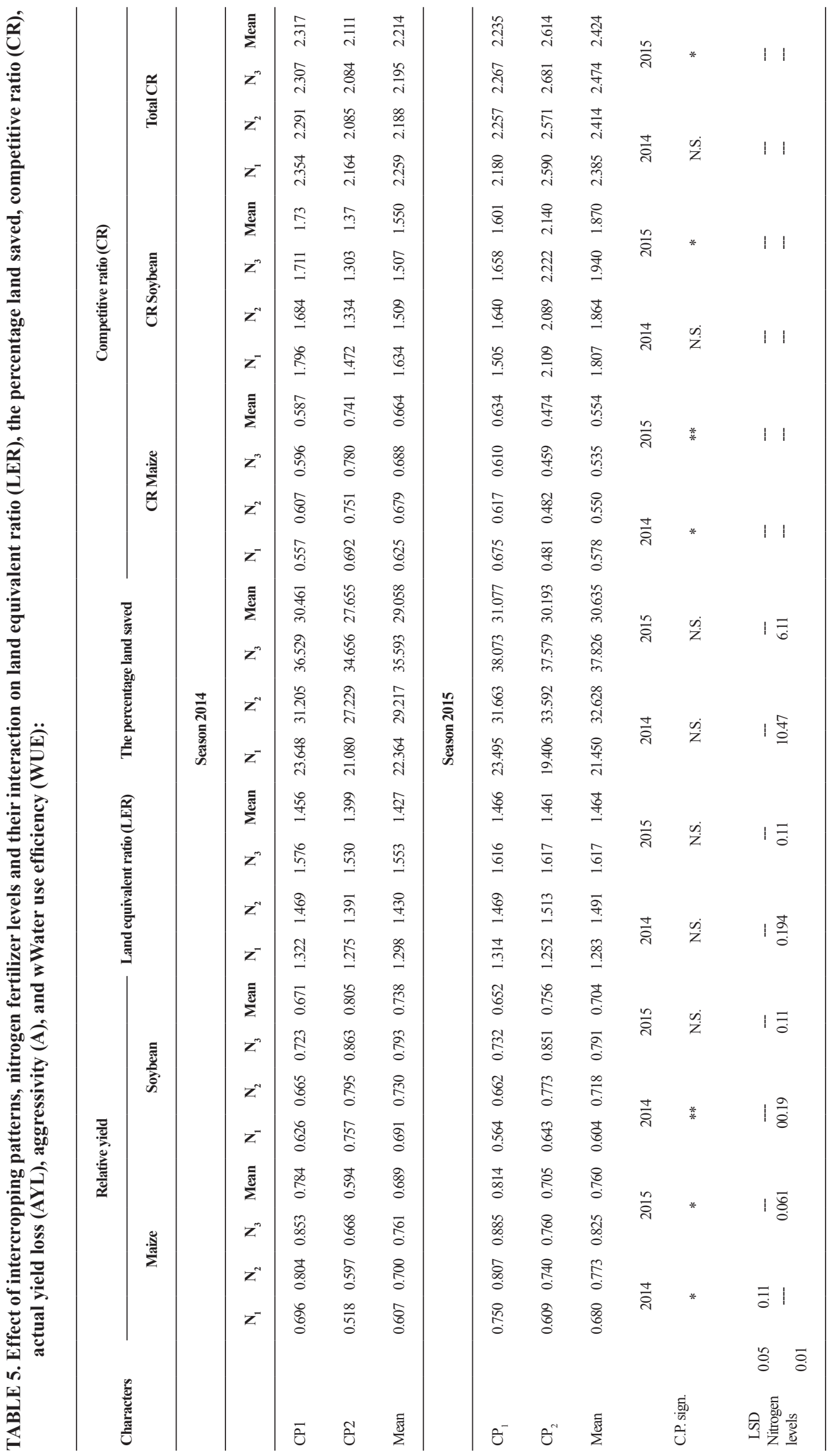




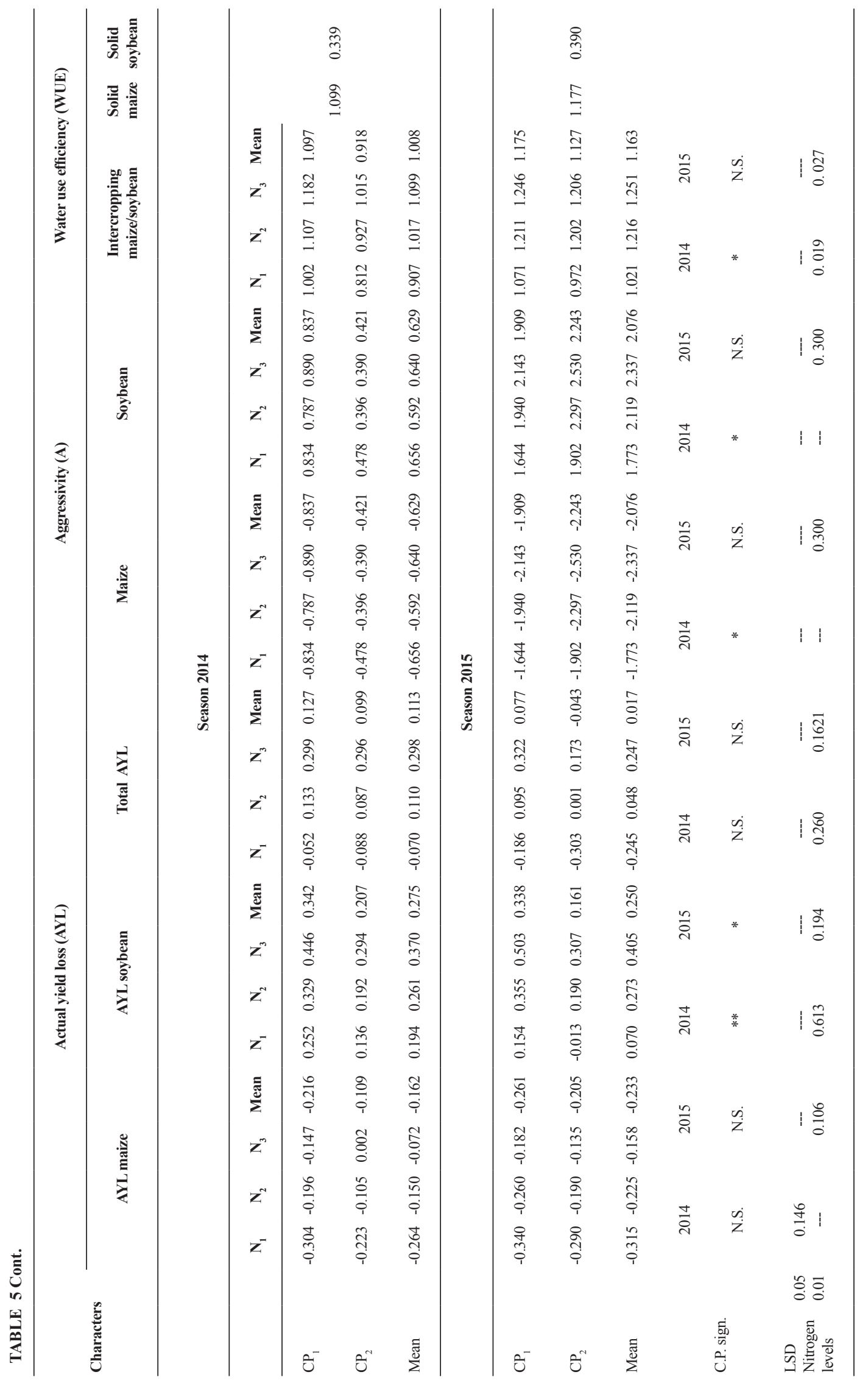

Egypt. J. Agron. 39, №. 3 (2017) 
In both seasons, the reduction of partial LER values of soybean crop was greater than obtained from maize crop under the intercropping pattern 2 maize: 2 soybean (CP1), while these reduction values of maize crop was greater than soybean crop under the intercropping pattern 2 maize: 4 soybean (CP2) which attributed to excess density of soybean plants under (CP2), and this data direction caused insignificant variation between the two intercropping patterns regarding to the total LER as well as the percentage land saved.

In both seasons, the total LER under the three nitrogen fertilizer levels were greater than one, indicating that the three nitrogen fertilizer levels had a yield advantage and saved land use.

The differences among the three nitrogen fertilizer levels regarding to the total LER and the percentage land saved were highly significant in both seasons (Table 5). The highest level of nitrogen $(120 \mathrm{~kg} / \mathrm{fad})$ recorded the highest values of total LER and the percentage land saved followed by the level of (100 kg N/fad), whereas the lowest level of nitrogen recorded the lowest values. These results are in agreement with those of Sadeghi \& Kazemeini (2012), Gadallah \& Gabra (2015) and Sebetha (2015) who mentioned that, the highest total land equivalent ratio (LER) for both crops was found under the highest nitrogen fertilizer application.

Effect of intercropping patterns and nitrogen fertilization levels on competitive ratio (CR), actual yield loss (AYL) and aggressivity (A)

Data in Table 5 showed that, the variations between the two intercropping patterns regarding to total competitive ratio (CR) and total AYL were significant only in the second season, while it didn't reach to the level of significance in the first one. The better (the lowest) competitive ratio (CR) was found for the intercropping pattern 2 maize: 4 soybean (CP2). Worthy to note that, in both seasons, all values of total $\mathrm{CR}$ were greater than 1 , suggesting that, under both patterns, competition between maize and soybean were so severe.

Worthy to mention that, values for competitive ratios for soybean were higher than maize values which revealed that, soybean was more competitive than maize, contradictory results were reported by Abou-Elela et al. (2012)

AYL maize had negative values. In the first season, there was a $21 \%$ and $10 \%$ decrease in yield of maize under the $\mathrm{CP} 1$ and $\mathrm{CP} 2$, respectively, while there were $26 \%$ and $20 \%$ decreases in yield of maize under the CP1 and CP2, respectively in the second one. On the other hand, AYL soybean had positive values. In the first season, there were $34 \%$ and $20 \%$ increases in yield of soybean under the CP1 and CP2, respectively, while there was a $33 \%$ and $16 \%$ increase in yield of soybean under the CP1 and CP2, respectively in the second one. In addition, the highest values of total AYL were recorded under the CP1 in both seasons.

The effect of the nitrogen fertilizer levels on total AYL was highly significant in both seasons, whereas the highest nitrogen fertilizer level (120 $\mathrm{kg} / \mathrm{fad}$ ) recorded the highest values of total AYL in both seasons.

Regarding to aggressivity (A), the differences between the two intercropping patterns were only significant in the first season, while it were insignificant in the second one. Under both intercropping patterns, positive $\mathrm{A}_{\text {soybean }}$ values showed that, soybean was the dominant specie over maize which had negative A values and considered the subordinate specie.

The effect of the nitrogen fertilizer levels on aggressivity was insignificant in the first season and highly significant in the second one, whereas the highest nitrogen fertilizer level $(120 \mathrm{~kg} / \mathrm{fad})$ recorded the highest values of aggressivity.

Worthy to mention that, the dominant behavior of soybean having competitive ratios values higher than maize, confirmed with positive $\mathrm{AYL}_{\text {soybean }}$ and positive $A_{\text {soybean }}$ values in case of intercropping with maize considered interesting data trend. This data counterfactual trend was due to that, maize was sown in hills spaced $30 \mathrm{~cm}$ and plants were thinned to two plants per hill in the intercropping treatments which is considered duplicate number of plants in hills compared with solid maize. This duplicate density in each hill caused a reductive activity of maize roots in all soil layers and significantly decreased dry weights of shallow roots, resulting in lower root biomass and consequently lower competitive ability for maize with soybean especially below-ground competition (Jiang et al., 2013). However, Lv et al. (2014) showed a greater contribution to intercrop advantages from below-ground interactions than above-ground interactions and reported that, competition for nutrients was more importance than competition 
for sunlight, confirming the importance of belowground competition. In addition, Caratti et al. (2016), mentioned that, under maize/soybean intercropping systems, when the root system was separated, preventing the competition for soil resources, the soybean productivity was similar to the monoculture productivity, which appeared as a highly competitive ability for soybean which had been sown with the optimum density in either intercropping or in solid soybean.

\section{Effect of intercropping patterns and nitrogen fertilization levels on water use efficiency:}

Data presented in Table 5 demonstrate that, WUE under the intercropping patterns tended to decrease with decreasing the proportions of intercropped maize due to the increment of grain yield of maize as a $\mathrm{C}_{4}$ plant compared with seed yield of soybean as a $\mathrm{C}_{3}$ plant, which increases the WUE values of maize crop comparing with those of soybean, as a result, WUE values under the CP1 were higher than those under CP2 and the differences were significant in the first season and didn't reach to the level of significance in the second one. Worthy to mention that, the solid maize had the highest WUE while the solid soybean had the lowest ones, in both seasons. The same trend was observed by El-Sherif \& Ali (2015), who reported that the WUE values of maize were higher than those of soybean due to increase grain yield of maize compared with seed yield of soybean. Also, Yuan et al. (2017), stated that, WUE under the intercropping arrangements decreased by the presence of soybean and the monocrop of maize had the highest WUE, while the monocrop of soybean had the lowest WUE.

Data cleared that, WUE was affected by the levels of nitrogen fertilizer and the differences among the three levels were highly significant in both seasons. It is obvious that, increasing the nitrogen fertilizer level increased significantly WUE and the highest values of WUE were recorded under the highest level of nitrogen $(120 \mathrm{~kg} / \mathrm{fad})$ and vise versa. These results were in alignment with our expectations considering that, raising the level of nitrogen increased maize and soybean yields and consequently enhanced WUE. Similar results were found by Bushong et al. (2014), who reported that, applying sufficient nitrogen fertilizer is most beneficial to grain yield and consequently WUE.

\section{Crop (maize) equivalent yield (CEY) and farmer's benefit}

As indicated in Table 6, the maize equivalent yield, total and net returns were higher under intercropping compared with solid maize cropping, meaning that, intercropping soybean with maize was more profitable to farmers than solid maize cropping, whereas the highest maize equivalent yield, total and net returns were obtained from the intercropping pattern 2 maize: 2 soybean (CP1), in both seasons. These increases were mainly due to additional yield advantage of intercropping. These findings are in the same trend with those obtained by Lamlom et al. (2015) and AbdelWahab \& Abd El-Rahman (2016), who reported that, intercropping gave higher total and net return over solid maize cropping.

With regards to nitrogen fertilizer levels; superiority of maize equivalent yield, total and net returns was noticed with the application of the highest nitrogen fertilizer level $(120 \mathrm{~kg} / \mathrm{fad})$, followed by the nitrogen fertilizer level $(100 \mathrm{~kg} /$ fad). On the other hand, the lowest nitrogen fertilizer level $(80 \mathrm{~kg} / \mathrm{fad})$ recorded the lowest values for these traits (Table 6). Similar results were recorded by (Naik et al., 2017). Worthy to note that, net returns under intercropping were lower than solid maize net returns under the lowest nitrogen fertilizer level $(80 \mathrm{~kg} / \mathrm{fad})$, which means economic losses for framers.

\section{Conclusion}

From this investigation it could be recapitulated that, the highest grain yield per fad for maize, No. of pods per plant, seed yield per plant for soybean, land equivalent ratio (LER), the percentage land saved, total actual yield loss (AYL), water use efficiency (WUE), crop (maize) equivalent yields (CEY), total and net returns were found under intercropping pattern CP1 (2 rows of maize: 2 rows of soybean, expressed as $100 \%$ maize $+50 \%$ soybean). While, the highest ear length, ear diameter, No. of rows/ear, grain yield/ ear for maize, seed yield/fad for soybean and the better (lowest) values for competitive characters were recorded from intercropping pattern CP2 (2 rows of maize: 4 rows of soybean, expressed as $66.66 \%$ maize $+66.66 \%$ soybean). Moreover, increasing the nitrogen fertilizer level from 80 to 120 units per fad increased all previous mentioned characters significantly.

In conclusion, these results revealed that, between the two tested intercropping patterns, it is recommended to apply CP1 with 120 nitrogen units per fad that accomplishes the highest profitable for farmers. 


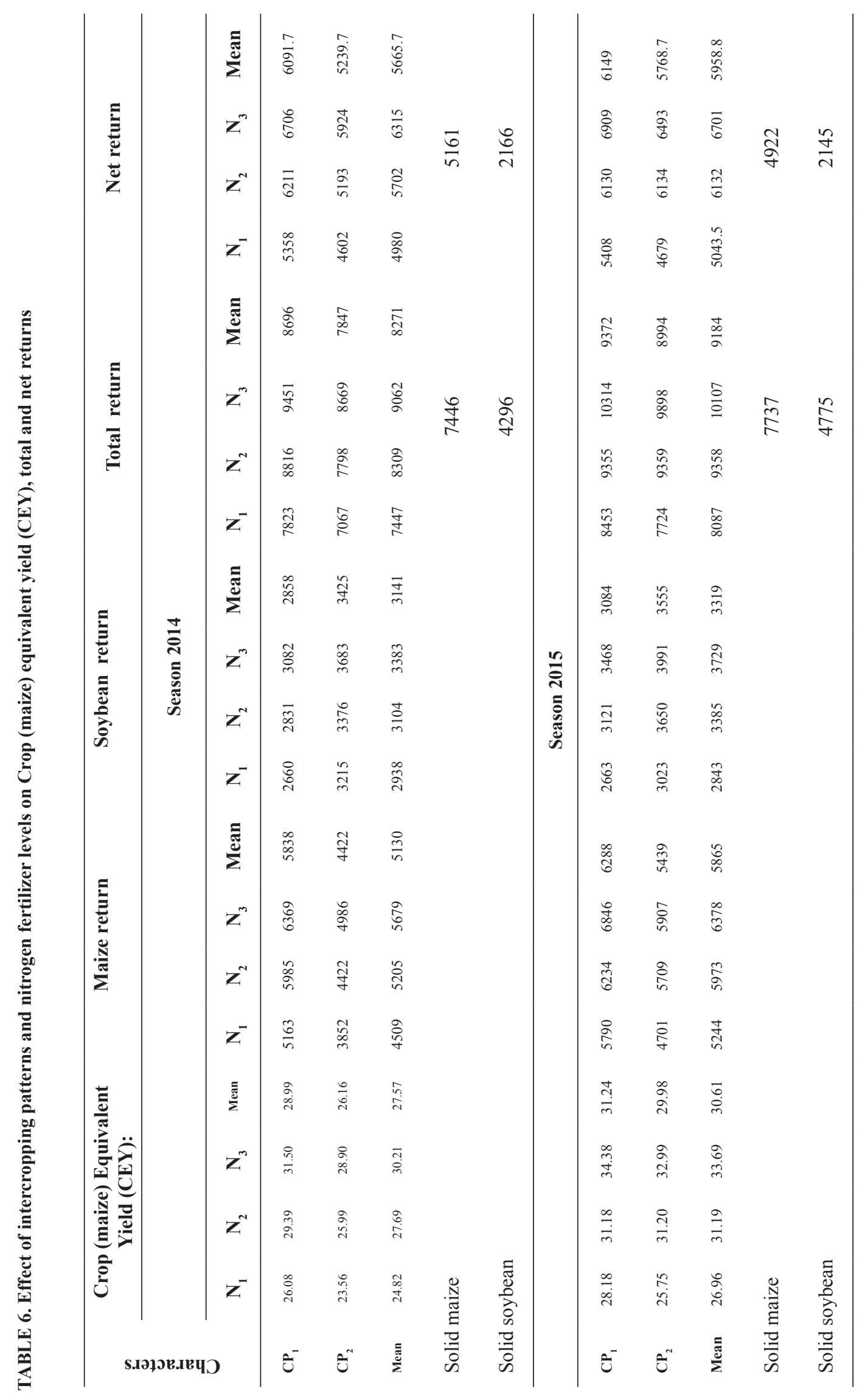




\section{References}

Abdel-Wahab, T.I. and Abd El-Rahman, R.A. (2016) Response of some soybean cultivars to low light intensity under different intercropping patterns with maize. International J. App. Agric. Sci. 2(2), 21-31.

Abou-Elela, A.M., Abd El-Razek, U.A. and Khalil, H.E. (2012) Yield and its components of maize/ soybean intercropping systems as affected by planting time and distribution. Australian Journal of Basic and Applied Sciences, 6(13), 238-245.

Banik, P. (1996) Evaluation of wheat (Triticum aestivum) and legume intercropping under 1:1 and 2:1 row replacement series system. Journal of Agronomy and Crop Science, 176, 289-294.

Beedy, T.L., Snapp, S., Akinnifesi, F. K. and Sileshi, G.W. (2010) Impact of Gliricidia sepium intercropping system. Agricultural Ecosystem and Environment, 138(3/4), 139- 146.

Brooker, R.W, Bennett, A.E., Feng -Cong, W., Daniell, T.J., George, T.S., Hallett, P.D., Cathy Hawes, C., Lannetta, P.P.M., Jones, H.G., Karley, A.J., Li, L., McKenzie, B.M., Pakeman, R.J., Paterson, E., Schob, C., Shen, J., Squire, G., Watson, C.A., Zhang, C., Zhang, F., Zhang, J. and White, P.J. (2015) Improving intercropping: A synthesis of research in agronomy, plant physiology and ecology. New Phytologist. 206, 107-117

Bulletin of Statistical Cost Production and Net Return (2014) Summer and Nili Field Crops and Vegetables and Fruit, Agriculture Statistics and Economic Sector, Ministry of Egyptian Agriculture and Land Reclamation, Part (2), August 2014.

Bushong, J.T., Arnall, D.B. and Raun, W.R. (2014) Effect of preplant irrigation, nitrogen fertilizer application timing, and phosphorus and potassium fertilization on winter wheat grain yield and water use Eefficiency. International Journal of Agronomy, (2014), Article ID 312416, 12 pages

Caratti, F.C., Lamego, F.P., Silva, J.D.G., Garcia, J.R. and Agostinetto, D. (2016) Partitioning of competition for resources between soybean and corn as competitor plant. Planta Daninha, ViçosaMG, v. 34, n. 4, p. 657-665

Dhima, K.V., Lithourgidis, A.S., Vasilakoglou, I.B. and Dordas, C.A. (2007) Competition indices of common vetch and cereal intercrops in two seeding ratio. Field Crops Research, 100, 249256.
Egbe, O.M., Alibo, S.E. and Nwueze, I. (2010) Evaluation of some extra-early-and early maturing cowpea varieties for intercropping with maize in southern Guinea Savanna of Nigeria. Agric. Biol. J. N. Am. 1(5), 845-858.

El-Sherif, A.M. and Ali, M.M. (2015) Effect of deficit irrigation and soybean/maize intercropping on yield and water use efficiency. Int. J. Curr. Microbiol. App.Sci. 4(12), 777-794.

Fathi, N.O. (2014) Crop yield and nitrogen bioavailability mediated by nitrogen fertilization in maize/soybean intercropping system with and without Rhizobium Inoculation. Alexandria Science Exchange Journal, 35(2).

Flynn, R. and Idowu, J. (2015) "Nitrogen Fixation by Legumes". Guide A-129, http://aces.nmsu.edu/ pubs/_a/A129/

Gadallah, R.A. and Gabra, A.M. (2015) Effect of intercropping patterns and nitrogen fertilization levels on yield and yield components of maize and soybean. Annals Agric. Sci., Moshtohor, 53(2), 187-197

Hussain, Z., Marwat, Kh., Munsif, F., Hashim, A.S. and Bakht, T. (2013) Influence of intercropping in maize on performance of weeds and the associated crops. Pak. J. Bot. 45(5), 1729-1734.

Jabbar, A., Ahmad, R., Bhatti, I.H., Virk, Z.A., Din, W.U. and Khan, M.M. (2009) Assessment of yield advantages, competitiveness and economic benefits of diversified direct-seeded upland ricebased intercropping systems under strip geometry of planting. Pak. J. Agri. Sci. 46(2), 96-101.

Jensen, M.E. (1983) Design and operation of farm irrigation systems. ASAE monograph, Revised printing No. 3 .

Jiang W., Wang, K., Wu, Q., Dong, S., Liu, P. and Zhang, J. (2013) Effects of narrow plant spacing on root distribution and physiological nitrogen use efficiency in summer maize. The Crop Journal, 1 (1), $77-83$

Lamlom, M.M., Abdel-Wahab, Sh.I., Abdel-Wahab, T.I. and Gendy E.K. (2015) Residual effects of some preceded winter field crops on productivity of intercropped soybean with three maize cultivars. American J. Bio Sci. 3(6), 226 - 242.

Loreau, M., Naeem, S., Inchausti, P., Bengtsson, J., Grime, J., Hector, A., Hooper, D., Huston, M., Raffaelli, D., Schmid, B., Tilman, D. and Wardle, D. (2001) Biodiversity and ecosystem functioning: current knowledge and future challenges. Science, 294, 804-808. 
Lv, Y., Francis, C., Wu, P., Chen, X. and Zhao, X. (2014) Maize-soybean intercropping interactions above and below ground. Crop Sci. 54, 914-922. doi:10.2135/ cropsci2013.06.0403

Matusso, J.M. (2014) Effects of maize (Zea mays L.) soybean (Glycine max L.) intercropping patterns on yields and soil properties in two contrasting sites of embu and meru counties, Kenya. M.Sc. Thesis. Kenyatta University. 112p.

Mead, R. and Willey, R.W. (1980) The concept of a land equivalent ratio and advantages in yields for intercropping. Exp. Agric. 16, 217-228.

Mettwally, A.A., Gamalat M.O., Sherief, M.N. and Awad, M.M. (2005) Yield and equivalent ratio of intercropped maize and groundnut. The $11^{\text {th }}$ Conf. Egypt Soc. Crop Sci, Assiut, pp. 163-173.

Metwally, A.A., Mohamed, G.O., Shereif, M.N. and Abo Hegazy, D.R.E. (2009) Yield and land equivalent ratio of intercropped corn and soybean under three intercropping patterns. $4^{\text {th }}$ Conference on Recent Technologies in Agriculture.

Miyazawa, K., Murakami, T., Takeda, M. and Murayama, T. (2010) Intercropping green manure crops-effects on rooting patterns. Plant and Soil, 331, 231-239.

Mouneke, C.O., Ogwuche, M.A.O. and Kalu, B.A. (2007) Effect of maize planting density on the performance of maize/soybean intercropping system in a Gguinea Savannah agroecosystem. African. J. Agric Res. 2(12), 667- 677.

Mousavi, S.R. and Eskandari, H. (2011) A general overview on intercropping and its advantages in sustainable agriculture. J. Appl. Environ. Biol. Sci. 1(11), 482-486

Naik, M.S.P., Sumathi, V. and Kadiri, L. (2017) Response of optimum nitrogen rate in maize with legume intercropping system. SAARC J. Agri. 15 (1), 139148.

Polthanee, A. and Trelo-Ges, V. (2003) Growth, yield and land use efficiency of corn and legumes grown under intercropping systems. Plant Prod. Sci. 6 (2), 139-146.

Putnam, D.H., Herbert, S.J. and Vargas, A. (1984) Intercropped corn soybean density studies. Yield complementarity. Expl. Agric. 21, 41-51.

Sadeghi, H. and Kazemeini, S.A. (2012) Interaction between different nitrogen fertilizer levels and maizebean intercropping patterns. J. Ecol. Field Biol. 35(4), 269-277.

Sani, Y.G., Jamshidi, K. and Moghadam, M.R. (2014)
Evaluation of quality and quantity of corn and soybean grain yield in intercropping under deficit irrigation. Journal of Biology, Agriculture and Healthcare, 4(25), 133-140.

Sebetha, E. (2015) The effect of maize-legume cropping system and nitrogen fertilization on yield, soil organic carbon and soil moisture. Ph.D. Thesis, School of Agriculture, Earth and Environmental Sciences, University of Kwazulu-Natal. 250p.

Snedecor, G.W. and Cochran, W.G. (1982) "Statistical Methods", $6^{\text {th }}$ ed., Iowa State Univ. Press, Ames., Iowa, USA.

Sonnewald, U. (2012). "Plant Physiology Preview". www.plant.org, American Society of Plant Biologists.

Thobatsi, T. (2009) Growth and yield responses of maize (Zea mays L.) and cowpea (Vigna unguiculata L.) in an intercropping system. M.Sc. Thesis, Faculty of Natural and Agricultural Sciences, University of Pretoria. 159p.

Undie, U.L., Uwah, D.F. and Attoe, E.E. (2010) The response of late season maize/soybean intercropping to nitrogen in the humid environment of South Southern Nigeria. J. Agric. Forestry and Social Sci. 8(2), 152- 165 .

Undie, U.L., Uwah, D.F. and Attoe, E.E. (2012) Growth and development of late season maize/soybean intercropping in response to nitrogen and crop arrangement in the forest agro-ecology of South Southern Nigeria. Inter. J. Agric. Res.7 (1), 1 - 16.

Verma, S.P. and Modgel, S.C. (1983) Production potential and economics of fertilizer application as resource constraints in maize wheat crop sequence.Himalayan J. Agric. Res. 9(2), 89-92.

Waktola, S.K., Belete, K. and Tana, T. (2014) Productivity evaluation of maize - soybean intercropping system under rain fed condition at Bench-Maji Zone, Ethiopia. Sky Journal of Agricultural Research, 3(9), $158-164$

Willey, R.W. (1985) Evaluation and presentation of intercropping advantages. Exploratory Agriculture, 21, 119- 133 .

Yuan, Y.R., Xiao, L.W., Zhang, S, Jairo, A.P. and Ying, L.C. (2017) Influence of spatial arrangement in maize-soybean intercropping on root growth and water use efficiency. Plant Soil, 415, 131-144.

Zhuang, L. and Yu-Bi, H. (2013) Function analysis of phytochrome $\mathrm{b}$ gene in maize. Pak. J. Bot. 45(4), 1215- 1220.

(Received 12 / 9 /2017; accepted $11 / 12$ /2017) 


\section{تأثيرنمطين تحميل لفول الصويا مع الذرة الثامية على المحصول ومكوناته تحت مستويات مختلفة من السماد النيتروجيني

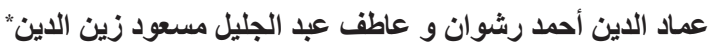

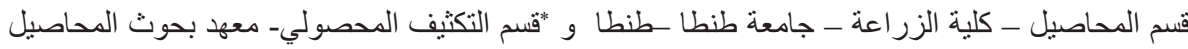

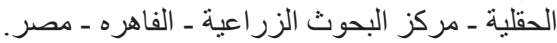

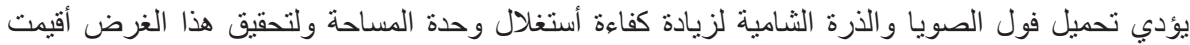

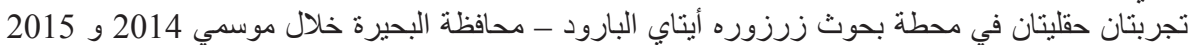

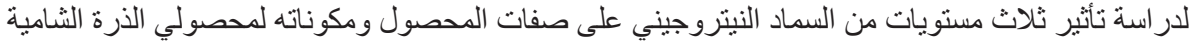

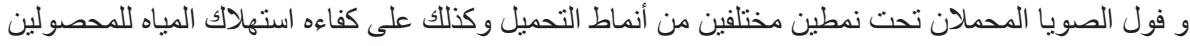

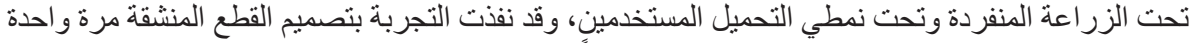

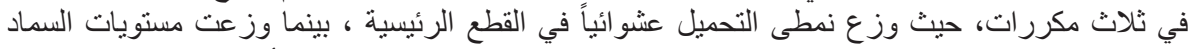

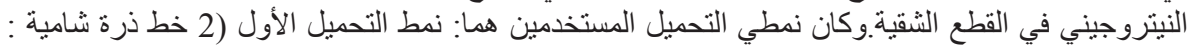

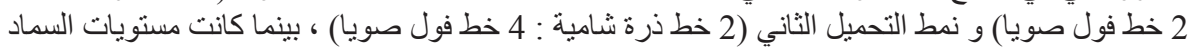

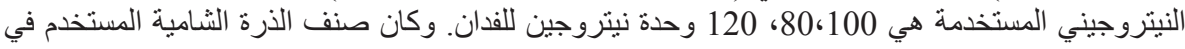

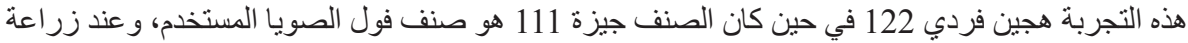

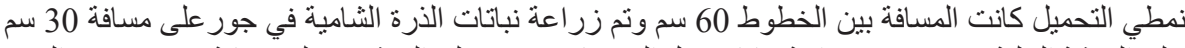

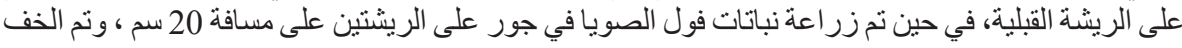

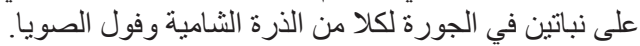

وقد أظهرت النتائج مايلي: أعلى قيم لصفات طول الكوز، قطر الكوز، عدد الصفوف على الكوز، محصول

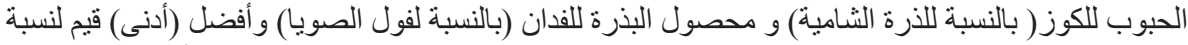

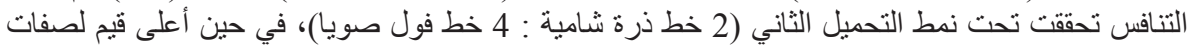

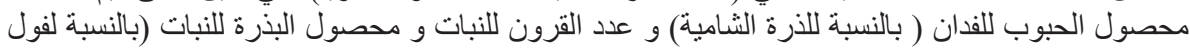

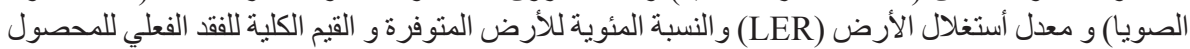
(Total AYL) وصافي العائد تحققت تحت نمط التحميل الأول (2 خط ذرة شامية : 2 خط فول صويا).

علاوة على ذلك، أدى زيادة مستوى التسميد النيتروجيني من 80 وحدة أزوت إلى 120 وحدة ازوت للفيدان

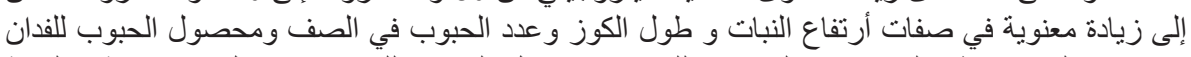

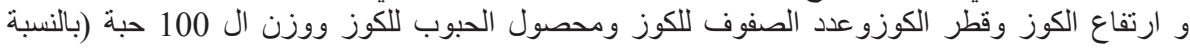

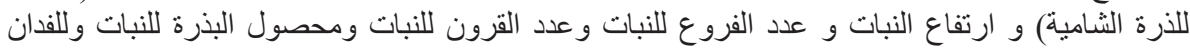

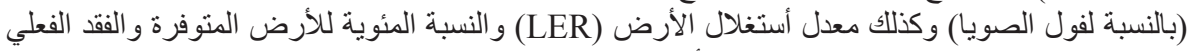

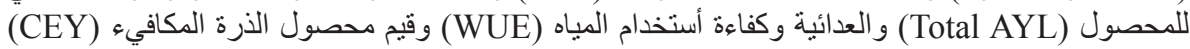

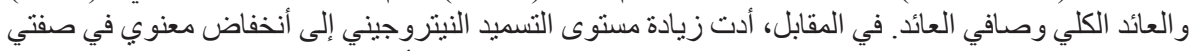

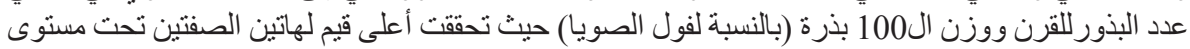
تسميد 80 وحدة أزوت للفدان. 